\title{
An Update on HIV-testing at a London Sexually Transmitted Diseases Clinic: long-term impact of the AIDS media campaigns
}

Eduard J Beck, Catrina Donegan, Colin Kenny, Colin S Cohen, Vincent Moss, Patrick Terry, Gill S Underhill, Donald J Jeffries, Anthony J Pinching, David L Miller, J R William Harris,

Deirdre G Cunningham

\begin{abstract}
Trends in the number of tests for HIV-1 antibody at a London sexually transmitted diseases clinic showed substantial changes between September 1985 and June 1988. From an average of 100 tests per month between September 1985 and August 1986, the average increased to 365 tests per month for September 1986 to August 1987. This levelled off at 243 tests per month between September 1987 and June 1988. The average number of positive tests per month between September 1985 and June 1988 remained constant, though the number of seropositive tests in females increased. Male and female populations displayed similar temporal patterns. The greatest increase was seen in the tests generated by heterosexual males
\end{abstract}

Academic Department of Public Health, St Mary's Hospital Medical School

Eduard J Beck, Catrina Donegan

Division of Virology, St Mary's Hospital

Colin Kenny

Department of Public Health, Parkside Health Authority

Colin S Cohen

Departments of Public Health and Genito Urinary

Medicine, St Mary's Hospital

Vincent Moss

Department of Genito Urinary Medicine, Royal

South Hants Hospital

Patrick Terry

Public Health Laboratory Service, Portsmouth

Gill S Underhill

Division of Virology, St Mary's Hospital Medical

School

Donald J Jeffries

Department of Immunology, St Mary's Hospital Medical School

Anthony J Pinching

Academic Department of Public Health, St Mary's Hospital Medical School

David L Miller

Department of Genito Urinary Medicine, St Mary's Hospital

J R William Harris

Department of Public Health, Parkside Health

Authority

Deirdre G Cunningham and females with no other risk factors. This group generated $42 \%$ of the 8012 tests performed during the study period. The Clinic's catchment area predominantly included London and surrounding areas and temporal patterns were similar for residents from each of the Thames Regions. The temporal patterns observed coincided with periods of increased media attention on HIV infection/AIDS and involved campaigns by the popular press, television, Department of Health and Social Security and the Health Education Authority. The increase in tests during the time of maximum media exposure, the subsequent plateau at a level substantially higher compared with the period preceding the media campaigns and the large increase in heterosexual males and females tested, all suggest that the campaigns have contributed to increasing awareness of HIV infection/AIDS as a major contemporary public health problem.

This paper describes long-term trends in HIV-1 tests performed at the Praed Street Clinic, the sexually transmitted diseases clinic of St Mary's Hospital an inner London teaching hospital and part of North West Thames Regional Health Authority. These trends have been monitored since September 1985 and the current study period extends to June 1988. The initial changes surrounding the $1986 / 1987$ UK AIDS media campaigns have been reported earlier. ${ }^{1}$

\section{Methods}

Individuals coming for HIV-1 testing were selfreferred or referred by a medical practitioner. All received pre- and post-test counselling. Demographic and behavioural data were collected using standardised methods and stored while preserving strict confidentiality. The behavioural characteristics of $83 \%(n=6685)$ of those tested were classified by criteria applied by clinicians at the time of pre-test counselling; for the remainder we depended on obtaining the data retrospectively from clinical records. 
All data were checked and coded by one of the authors $(C D)$ and entered on a database programme, using dBase III Plus ${ }^{\mathrm{R}}$. Upon completion, the database files were transferred from dBase to SPSS.PC ${ }^{R}$ and the analysis performed on an IBM microcomputer in the Department of Public Health. All HIV tests were performed by the Division of Virology. A competitive ELISA (Wellcome ${ }^{R}$ ) was used as an initial screening test, whilst all positive results were checked by using an antibody capture ELISA $\left(\mathrm{Abbott}^{\mathrm{R}}\right.$ ). All equivocal results were checked by Western blot technique. This procedure has been used by us for some time and is now being considered by other British laboratories. ${ }^{2}$

\section{Results}

Between September 1985 and June 1988, the Clinic recorded a total of 164742 patient visits. Of these $66 \%(n=108918)$ were new visits and $34 \%$ were follow-up visits. Of all visits $58 \%(n=95008)$ were made by men and $42 \%(n=69734)$ by women. Sixty four per cent of the male visits and $69 \%$ of the female visits were first time attendances and the remainder follow-up visits.

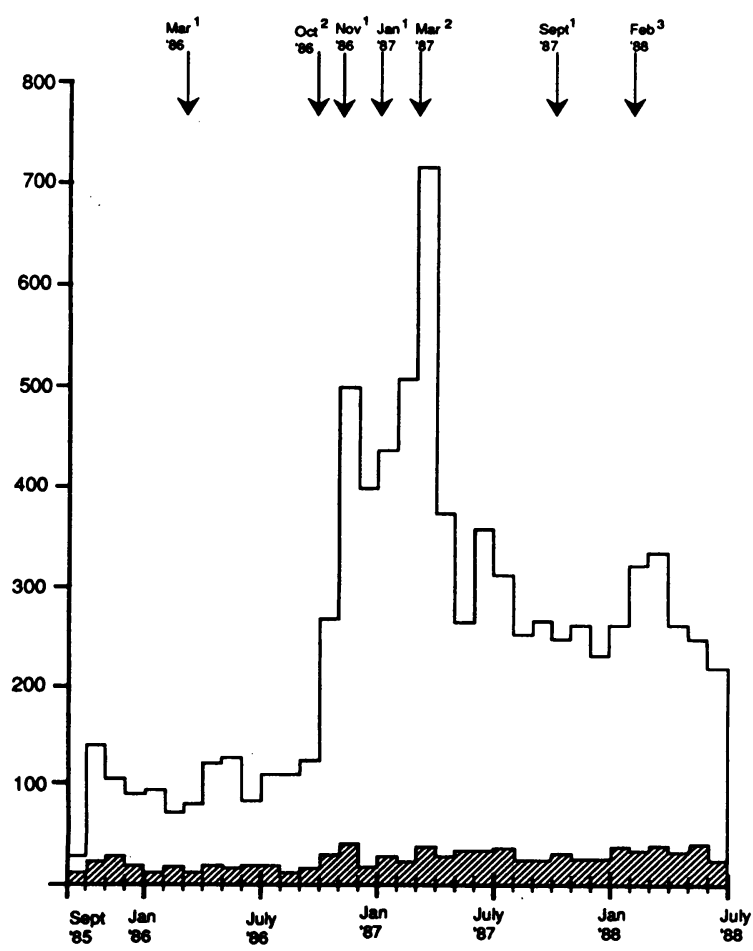

Figure 1 HIV tests performed on the total population between September 1985 and June 1988 including the temporal relationship with the various HIV|AIDS media campaigns held during the study period:

$1=$ Department of Health and Social Security

2 = Popular press $/ T V$

3 = Health Education Authority

(Shaded areas are positive tests).
During this period, $8012 \mathrm{HIV}$ tests were performed. As each test incurs at least two Clinic visits, for pre- and post-test counselling, HIV-testing constituted $10 \%$ of the Clinic's total number of visits. These 8012 tests were performed on 6923 individuals and 1089 were therefore follow-up tests. Overall $91.5 \%(n=7328)$ tests were negative and $684(8.5 \%)$ positive.

From September 1985 to September 1986 the number of tests performed was relatively stable. An increase occurred between October 1986 and April 1987, peaking in March 1987. During the period May 1987 to June 1988, the number of tests performed stabilised again. For the first 12 month period an average of 100 tests were performed per month. This increased to an average of 365 tests per month for the period September 1986 to August 1987, and fell between September 1987 and June 1988 to 243 tests per month.

The average number of positive tests performed
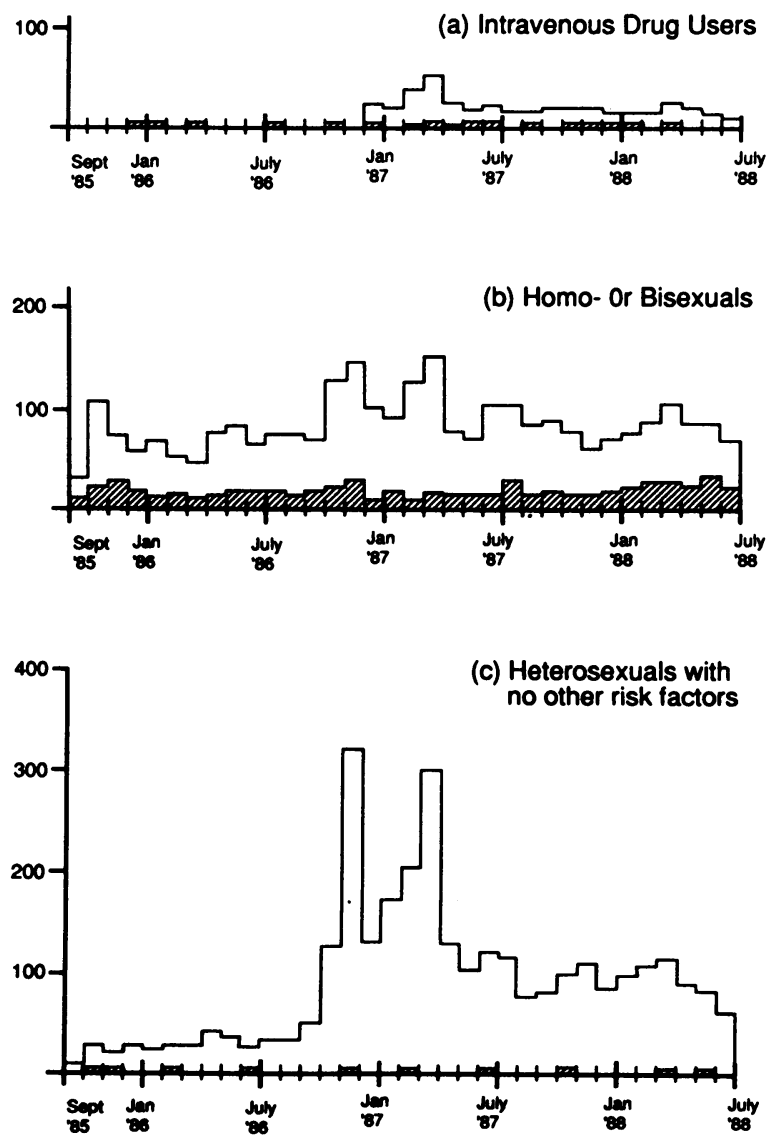

Figure 2 Tests performed on intravenous drug users, homoor bisexuals and heterosexuals with no other risk factors per month during the study period, September 1985 to June 1988.

(Shaded areas represent positive tests). 
during each period was 16,22 and 23 per month respectively. The changing trends coincided temporally with increased media activity devoted to AIDS/HIV infection (fig 1 ). Of all tests, $67 \%(n=$ 5354) were performed on men, and 2658 on women. Of the male tests, $630(12 \%)$ were positive, compared with $2 \%(n=54)$ in women. Though similar time trends were observed for men and women and the overall number of tests generated by males exceeded that for women, the rate of increase was found to be greatest among women.

Ninety six per cent $(n=7819)$ of the 8012 tests performed could be assigned to individuals of a known risk group. For the remaining $4 \%$, behavioural data were unavailable. Heterosexuals with no other risk factor generated $42 \%$ of all tests, homosexual or bisexual individuals generated $37 \%$ of the tests and $4 \%$ were intravenous drug users. The
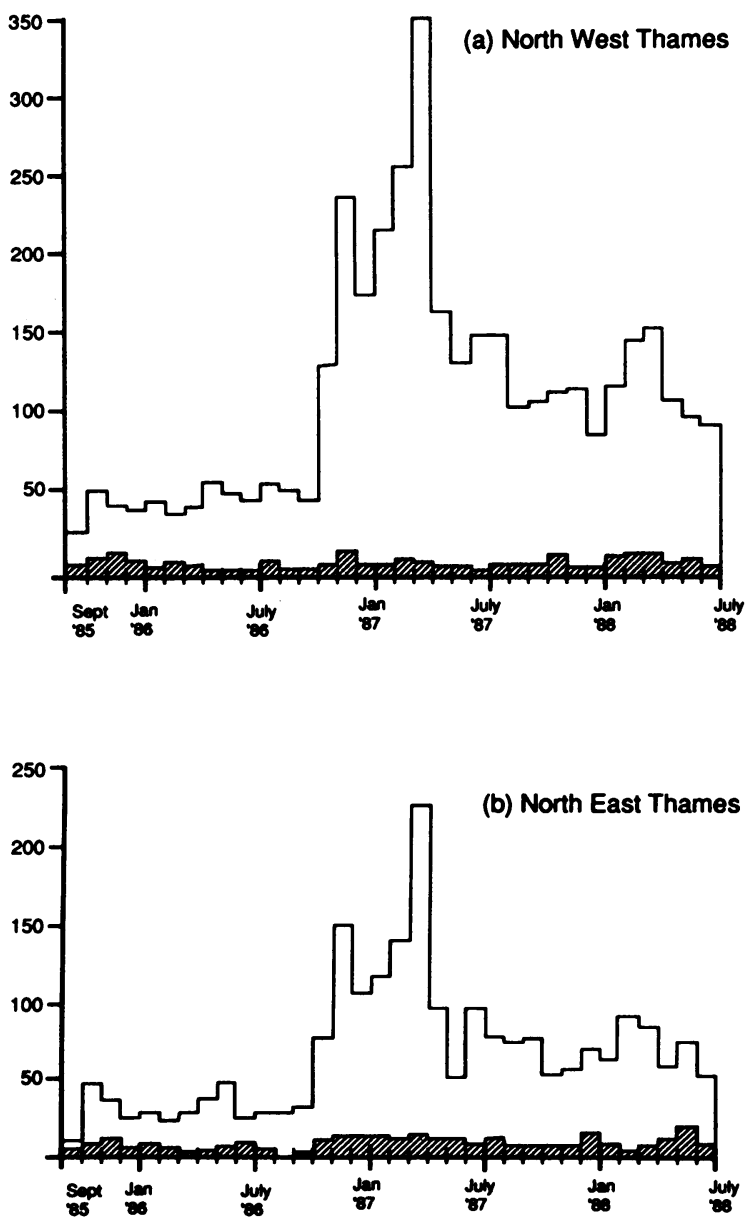

Figure 3 Tests performed on residents of various English Regional Health Authorities per month during the study period, September 1985 to June 1988.

(Shaded areas are positive tests).

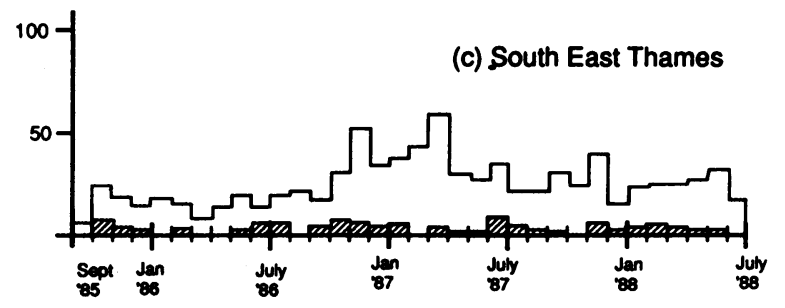

(d) South West Thames

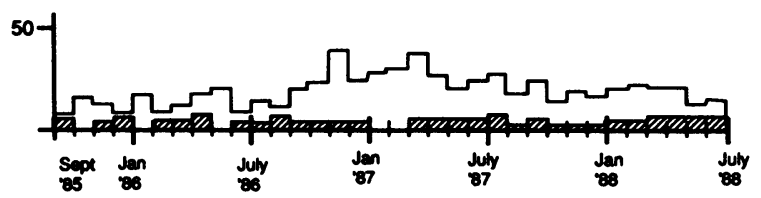

(e) Other English Regions

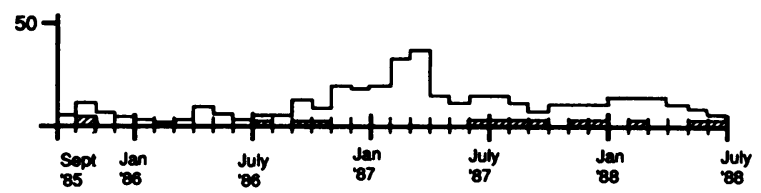

majority $(80 \%)$ of the seropositive tests were in male homosexual or bisexual individuals. Of the heterosexuals with no other risk factor $(n=3263) 11$ tests were positive: 5 in men $(n=1652)$ and 6 in females ( $n$ $=1611$ ). Differences over time were also observed between the various risk groups. Between September 1985 and August 1986 an average of 67 tests per month were performed on homosexual or bisexual individuals. This increased to 109 tests between September 1986 and August 1987, which subsequently declined to a monthly average of 75 between September 1987 and June 1988. The average number of positive tests in this group per month rose from 14, 16 to 17 respectively for the three periods (fig 2). Similar, though less pronounced, trends were observed for tests on intravenous drug users (fig 2). The greatest increase in tests was seen among heterosexuals with no other risk factor. An average of 28 tests per month were generated by these individuals between September 1985 and August 1986. This increased to an average of 164 per month between September 1986 and August 1987 and declined to 80 tests per month between September 1987 and June 1988. Of the 11 seropositive tests in this group four were observed in the first period, three in the second and a further four during the third period (fig 2).

Ninety seven per cent $(n=7745)$ of tests were performed on individuals whose reported area of residence was known. Of these $49 \%$ resided within 
North West Thames Regional Health Authority (NWT) (table 1), 31\% within North East Thames Regional Health Authority (NET), 10\% within South East Thames Regional Health Authority
(SET) and 6\% within South West Thames Regional Health Authority (SWT). Altogether $96 \%$ of tests were generated by Thames residents. The distribution of seropositive tests by area of residence was

Table 1 Tests generated for total, male and female population by residential area. (UK specified according to Regional Health Authorities)

\begin{tabular}{|c|c|c|c|c|c|c|c|}
\hline & & \multicolumn{2}{|l|}{ Total } & \multicolumn{2}{|l|}{ Male } & \multicolumn{2}{|c|}{ Female } \\
\hline & & $n$ & $(+) v e$ & $n$ & $(+) v e$ & $n$ & $(+) v e$ \\
\hline $\begin{array}{l}\text { Inner } \\
\text { Outer }\end{array}$ & $\begin{array}{l}\text { London NWT } \\
\text { London NWT } \\
\text { Shires NWT }\end{array}$ & $\begin{array}{r}2333 \\
962 \\
460\end{array}$ & $\begin{array}{r}176 \\
66 \\
43\end{array}$ & $\begin{array}{r}1439 \\
615 \\
333\end{array}$ & $\begin{array}{r}161 \\
58 \\
34\end{array}$ & $\begin{array}{l}894 \\
347 \\
127\end{array}$ & $\begin{array}{r}15 \\
8 \\
9\end{array}$ \\
\hline & NWT & 3755 & 285 & 2387 & 253 & 1368 & 32 \\
\hline $\begin{array}{l}\text { Inner } \\
\text { Outer }\end{array}$ & $\begin{array}{l}\text { London NET } \\
\text { London NET } \\
\text { Shires NET }\end{array}$ & $\begin{array}{r}1532 \\
718 \\
118\end{array}$ & $\begin{array}{r}128 \\
64 \\
9\end{array}$ & $\begin{array}{r}965 \\
488 \\
92\end{array}$ & $\begin{array}{r}118 \\
63 \\
8\end{array}$ & $\begin{array}{r}567 \\
230 \\
26 \\
\end{array}$ & $\begin{array}{r}10 \\
1 \\
1 \\
\end{array}$ \\
\hline & NET & 2368 & 201 & 1545 & 189 & 823 & 12 \\
\hline $\begin{array}{l}\text { Inner } \\
\text { Outer }\end{array}$ & $\begin{array}{l}\text { London SET } \\
\text { London SET } \\
\text { Shires SET }\end{array}$ & $\begin{array}{r}645 \\
15 \\
90\end{array}$ & $\begin{array}{r}69 \\
1 \\
2\end{array}$ & $\begin{array}{r}475 \\
11 \\
69\end{array}$ & $\begin{array}{r}64 \\
1 \\
2\end{array}$ & $\begin{array}{r}170 \\
4 \\
21\end{array}$ & $\frac{5}{-}$ \\
\hline & SET & 750 & 72 & 490 & 67 & 195 & 5 \\
\hline $\begin{array}{l}\text { Inner } \\
\text { Outer }\end{array}$ & $\begin{array}{l}\text { London SWT } \\
\text { London SWT } \\
\text { Shires SWT }\end{array}$ & $\begin{array}{l}165 \\
147 \\
170\end{array}$ & $\begin{array}{l}24 \\
24 \\
15\end{array}$ & $\begin{array}{l}118 \\
105 \\
133 \\
\end{array}$ & $\begin{array}{l}21 \\
24 \\
15\end{array}$ & $\begin{array}{l}47 \\
42 \\
37 \\
\end{array}$ & $\frac{3}{-}$ \\
\hline & SWT & 482 & 63 & 356 & 60 & 126 & 3 \\
\hline & $\begin{array}{l}\text { Wessex } \\
\text { Oxford } \\
\text { East Anglia } \\
\text { South Western } \\
\text { West Midlands } \\
\text { Trent } \\
\text { Mersey } \\
\text { North Western } \\
\text { Yorkshire } \\
\text { Northern } \\
\text { Rest of UK }\end{array}$ & $\begin{array}{r}54 \\
140 \\
34 \\
27 \\
27 \\
12 \\
9 \\
5 \\
8 \\
3 \\
19\end{array}$ & $\begin{array}{l}3 \\
6 \\
1 \\
2 \\
1 \\
- \\
\\
2 \\
3\end{array}$ & $\begin{array}{r}36 \\
116 \\
27 \\
20 \\
21 \\
7 \\
8 \\
2 \\
4 \\
3 \\
15\end{array}$ & $\begin{array}{l}3 \\
5 \\
1 \\
2 \\
1 \\
- \\
- \\
2 \\
3\end{array}$ & $\begin{array}{r}18 \\
24 \\
7 \\
7 \\
6 \\
5 \\
1 \\
3 \\
4 \\
-4\end{array}$ & $\begin{array}{l}\overline{1} \\
= \\
= \\
= \\
= \\
=\end{array}$ \\
\hline $\begin{array}{l}\text { Rest of } \\
\text { North }\end{array}$ & $\begin{array}{l}\text { Europe } \\
\text { America }\end{array}$ & $\begin{array}{r}26 \\
5\end{array}$ & 3 & $\begin{array}{r}22 \\
4\end{array}$ & 3 & $\begin{array}{l}4 \\
1\end{array}$ & 二 \\
\hline South & America & 1 & 1 & 1 & 1 & - & - \\
\hline Africa & & 6 & 2 & 6 & 2 & - & - \\
\hline $\begin{array}{l}\text { Middle } \\
\text { Asia }\end{array}$ & e East & $\begin{array}{r}10 \\
4\end{array}$ & - & $\begin{array}{l}6 \\
3\end{array}$ & - & $\begin{array}{l}4 \\
1\end{array}$ & 二 \\
\hline As1a & & 7745 & 645 & 5144 & 592 & 2601 & 53 \\
\hline Unkno & wn & 267 & 39 & 210 & 38 & 57 & 1 \\
\hline
\end{tabular}

Table 2

\begin{tabular}{|c|c|c|c|c|c|c|}
\hline & $\begin{array}{l}\text { Inner } \\
\text { London }\end{array}$ & $\begin{array}{l}\text { Outer } \\
\text { London }\end{array}$ & $\begin{array}{l}\text { Thames } \\
\text { Shires }\end{array}$ & $\begin{array}{l}\text { Other English } \\
\text { Regions }\end{array}$ & Rest of $U K$ & Total \\
\hline \multicolumn{7}{|c|}{ (a) Distribution of tests generated by all UK residents by gender and residential area } \\
\hline \multirow[t]{2}{*}{$\begin{array}{l}\text { Male } \\
\text { Female }\end{array}$} & $\begin{array}{l}2997(64 \cdot 1) \\
1678(35 \cdot 9) \\
4675\end{array}$ & $\begin{array}{r}1219(66 \cdot 2) \\
623(33 \cdot 8) \\
1842\end{array}$ & $\begin{array}{l}627(74 \cdot 8) \\
211(25 \cdot 2) \\
838\end{array}$ & $\begin{array}{l}244(76 \cdot 5) \\
75(23 \cdot 5) \\
319\end{array}$ & $\begin{array}{c}15(78 \cdot 9) \\
4(21 \cdot 1) \\
19\end{array}$ & $\begin{array}{l}5102(66 \cdot 3) \\
2591(33 \cdot 7) \\
7693\end{array}$ \\
\hline & $\chi^{2}=53 \cdot 5, \mathrm{D}$ & $=0.0000$ & & & & Unknown 319 \\
\hline \multicolumn{7}{|c|}{ (b) Distribution of tests and tests results generated by all UK males by residential area } \\
\hline $\begin{array}{l}\text { Negative } \\
\text { Positive }\end{array}$ & $\begin{array}{l}2633(87 \cdot 8) \\
364(12 \cdot 2) \\
2997 \\
\chi^{2}=13 \cdot 2, \mathrm{D}\end{array}$ & $\begin{array}{l}1073(88.0) \\
146(12.0) \\
1219 \\
=0.01\end{array}$ & $\begin{array}{l}568(90 \cdot 6) \\
59(9 \cdot 4) \\
627\end{array}$ & $\begin{array}{l}230(94 \cdot 3) \\
14(5 \cdot 7) \\
244\end{array}$ & $\begin{array}{l}12(80 \cdot 0) \\
3(20 \cdot 0) \\
15\end{array}$ & $\begin{array}{l}4516(88.5) \\
586(11 \cdot 5) \\
5102 \\
\text { Unknown } 252\end{array}$ \\
\hline \multicolumn{7}{|c|}{ (c) Distribution of tests and tests results generated by all $U K$ females by residential area } \\
\hline $\begin{array}{l}\text { Negative } \\
\text { Positive }\end{array}$ & $\begin{array}{c}1645(98 \cdot 0) \\
33(2 \cdot 0) \\
1678 \\
\chi^{2}=9 \cdot 1, \mathrm{DF}\end{array}$ & $\begin{aligned} & 614(98.5) \\
& 9(1.5) \\
& 623 \\
&= 0.06\end{aligned}$ & $\begin{array}{l}201(95 \cdot 3) \\
10(4 \cdot 7) \\
211\end{array}$ & $\begin{array}{l}74(98 \cdot 7) \\
1(1 \cdot 3) \\
75\end{array}$ & $\frac{4}{4}$ & $\begin{array}{l}2538(98 \cdot 0) \\
53(2 \cdot 0) \\
2591\end{array}$ \\
\hline
\end{tabular}


similar to that of the total population. The Thames residents also generated the bulk $(96 \%)$ of the seropositive tests. Over time, trends in the number of tests from the various regions displayed a pattern similar to that described for the total population (fig 3). The number of seropositive tests remained fairly constant for residents of all regions.

Considering tests generated by UK residents $(\mathrm{n}=$ 7693), the number of tests performed decreased, as the distance of residence from the Clinic increased (table 2a), with most tests generated by London residents. This inverse relationship existed for the total, the male and female populations. However, the proportion of tests generated by males compared to females increased with increasing residential distance from the Clinic. Thus inner London males generated $64 \%$ of tests which increased to $77 \%$ for the other English regions. All risk groups displayed the inverse relationship between number of tests performed and residential distance from the Clinic, but heterosexuals with no other risk factors accounted for most of the male-female differences observed in the total population.

Significant differences in residential area were observed by test-result. This was, however, more apparent for the seropositive males compared to the seropositive women (tables $2 \mathrm{~b}$ and $2 \mathrm{c}$ ). No significant differences were observed between the various risk groups, for residential area and test result. Finally, the number of HIV tests performed is governed by both patient "demand" and staff "supply". Conceivably the increase in tests performed could be secondary to altered tests ordering behaviour by the medical staff. This, however, was not borne out during informal discussions with them.

\section{Discussion}

The initial increase in the number of HIV tests performed during the British media campaigns has already been reported by us. ${ }^{1}$ Similar changes have been reported by other clinics in London, ${ }^{3}$ Sheffield, ${ }^{4}$ Liverpool, ${ }^{5}$ Leeds, ${ }^{6}$ and Scotland ${ }^{7}$ though to date no long-term follow-up studies have been published. In the months subsequent to the period of maximum media exposure on HIV infection/AIDS there was a fall in the number of tests performed, but the average during this period remained well above that for the period preceding the media campaigns. Both males and females generated increased number of tests; the absolute number of tests performed on males exceeded those on women, whilst the rate of increase for the latter was greater than for the former. Males continued to generate the greatest number of seropositive tests and these remained relatively constant over the total study period. This is in contrast to national trends, where the overall increase in the number of HIV tests performed during the early part of 1987 was accompanied by an increase in sero- positive tests, especially among homosexual or bisexual men. ${ }^{8}$ This discrepancy suggests that referral and self-referred patterns to this Clinic among homosexual or bisexual men during the study period were already at near maximum levels. Whilst all groups displayed similar temporal patterns, the rate of increase in tests performed since October 1986 has been greatest for the heterosexual males and females, especially when compared to the homosexual or bisexual groups (fig 2).

The sustained increase in tests following the October 1986-March 1987 media campaigns suggests a greater public awareness of HIV infection and its causes. This can also be inferred from the increased number of heterosexual males and females with no other risk factors who came for testing to the Clinic, and by opinion polls on this topic around the time of the media campaigns. ${ }^{9}$ The media campaigns seem to have contributed to the awareness of HIV infection/AIDS as a major contemporary public health problem.

Some aspects of the initial mass-campaigns, both in Britain and elsewhere, have recently been criticised. One criticism has been that the campaigns were directed at mass audiences rather than targeted on specific groups. ${ }^{10}$ The first British Government advertisements appeared in March 1986. By September 1986 the popular press had picked up the story of heterosexual transmission, partly from the Second International Conference on AIDS in Paris, whilst the Government follow-up campaigns occurred in November 1986 and January 1987. Since these campaigns and AIDS week in March 1987, a number of targeted campaigns have reinforced some of the earlier messages in a more sophisticated format. The implications of the prevention paradox ${ }^{11}$ are that if educational campaigns are to be successful they need to operate at two levels. In short, the principle states that small changes in a larger number of individuals will effect greater population changes than large changes in a smaller number of individuals. In this context, the strategy of commencing with a general mass campaign, to put the topic on the "health agenda", complemented by targeted campaigns and reinforcement seems very reasonable. Both mass and targeted campaigns, however, need to be effective both in their educational message and their delivery.

Finally, whilst HIV-tests can currently be used as indicators of the consultative process which takes place between professionals and those seeking their advice, they underestimate the actual number of HIV-related Clinic consultations ${ }^{1}$ and form only a part of this process. The resource implications of an increased workload and the specific effects of publicity campaigns are evident. Though the majority of the individuals tested were seronegative, this consultative process must remain an integral part 
of the overall educational process, whereby the general message can be discussed and evaluated within the context of the worried individual seeking professional advice.

This work was only possible through the ongoing collaboration between staff members of the Praed Street Clinic, Division of Virology and Departments of Public Health. We are especially indebted to Kay English, Irma Bishop, and Yvonne Brennan and Ann Lee for their secretarial support.

Address for correspondence: Dr E J Beck, Academic Department of Public Health, St Mary's Hospital Medical School, Praed Street, London W2 1PG, UK.

1 Beck EJ, Cunningham DG, Moss VW, Harris JRW, Pinching AJ, Jeffries DJ. HIV Testing: changing trends at a clinic for sexually transmitted diseases in London. $\mathrm{Br}$ Med J 1987; 295:191-3.
2 Day A, Mortimer PP. Simplified confirmatory HIV testing. Lancet 1988;i1:509-10.

3 Sonnex C, Petherick A, Adler MW, Miller D. HIV infection: increase in public awareness and anxiety. $\mathrm{Br} M e d J 1987$; 295:193-5.

4 Woolley PD, Kinghorn GR. AIDS publicity campaigns. Lancet 1987;ii:284.

5 Turner GC, Mutton KJ. HIV testing: changing trends. $\mathrm{Br}$ Med $J$ 1987;295:502.

6 Clarke J, Waugh MA, Lacey CJN, Hambling MH. HIV antibody testing: experience in a provincial sexually transmitted diseases clinic. Public Health 1988;102:251-5.

7 Joshi UY, Cameron SO, Sommerville JM, Sommerville RG. HIV testing in Glasgow Genito-Urinary Medicine Clinics 1985-1987. Scot Med J 1988;33:294-5.

8 Bannister BA, Clarke SE, Ellam GA, et al. Human Immunodeficiency Virus infection in the United Kingdom: Quarterly Report 2. J Infection 1988;17:71-82.

9 DHSS AIDS: monitoring response to the public education campaign February 1986-February 1987. London: HMSO, 1987:47-58.

10 International Planned Parenthood Federation. Preventing a Crisis: AIDS and Family Planning Work. IPPF Distribution Unit, London, 1988.

11 Rose G. Sick individuals and sick populations. Int J Epidemiol 1985;14:32-8.

Accepted for publication 20 February 1990 